\title{
Larval Gnathostomes and Zoonotic Trematode Metacercariae in Fish from a Local Market in Yangon City, Myanmar
}

\author{
Jong-Yil Chai ${ }^{1,2} \mathbb{C}$, Bong-Kwang Jung ${ }^{1} \mathbb{C}$, Keon Hoon Lee ${ }^{1}$, Jin-Youp Ryu', Hyeon-Seung Kim¹, Sung-Jong Hong ${ }^{3} \mathbb{C}$, \\ Thi Thi Htoon ${ }^{4}$, Htay Htay Tin ${ }^{4}$, Byoung-Kuk Na ${ }^{5}$ [i], Woon-Mok Sohn ${ }^{5, *}$ (i) \\ 1'Institute of Parasitic Diseases, Korea Association of Health Promotion, Seoul 07649, Korea; ${ }^{2}$ Department of Tropical Medicine and Parasitology, \\ Seoul National University College of Medicine, Seoul 03080, Korea; ${ }^{3}$ Department of Environmental Medical Biology, Chung-Ang University College \\ of Medicine, Seoul 06974, Korea; ${ }^{4}$ National Health Laboratory, Yangon 11191, Myanmar; ${ }^{5}$ Department of Parasitology and Tropical Medicine, and \\ Institute of Health Sciences, Gyeongsang National University College of Medicine, Jinju 52727, Korea
}

\begin{abstract}
A survey was performed to investigate the infection status of zoonotic helminth larvae in fish from a local market of North Dagon District in Yangon City, Myanmar. A total of 486 fish in 13 species were collected 8 times from December 2015 to December 2019. All fish were transported under ice to a laboratory in Korea and examined for helminth larvae using artificial digestion method. Larval gnathostomes and metacercariae of more than 8 zoonotic trematode species, i.e., Opisthorchis viverrini, Haplorchis taichui, H. pumilio, H. yokogawai, Centrocestus spp., Stellantchasmus falcatus, Pygidiopsis cambodiensis, and Procerovum sp., were detected. Larval gnathostomes were found in 58 (16.0\%) out of 362 fish of 6 species, with mean intensity of 2.8 per fish infected. Metacercariae of 0 . viverrini were detected in $10(2.9 \%)$ out of 349 fish of 5 species, with mean intensity of 16.9 per fish infected. Metacercarial prevalences of 4 intestinal flukes, $H$. taichui, $H$. pumilio, $H$. yokogawai, and Centrocestus spp., were $16.8 \%, 26.0 \%, 12.5 \%$, and $15.0 \%$ in the positive fish species, respectively, and mean metacercarial intensity was 63.3, 26.8, 86.2, and 8.7 per fish infected. Metacercariae of $S$. falcatus and $P$. cambodiensis were detected only from the mullet, Chelon macrolepis. Metacercariae of Procerovum sp. were found in Channa striata and Anabas testudineus. Collectively, it was confirmed that the fish were infected with gnathostome larvae and metacercariae of $O$. viverrini and intestinal flukes in Yangon City, Myanmar.
\end{abstract}

Key words: Gnathostoma sp., Opisthorchis viverrini, Haplorchis taichui, Haplorchis pumilio, Haplorchis yokogawai, Stellantchasmus falcatus, Pygidiopsis cambodienesis, Centrocestus spp., Procerovum sp., zoonotic helminth larva

Fishborne-zoonotic helminths (FZH), including Gnathosto$m a$ spp. and trematodes, provoke a remarkable morbidity in residents of some Asian countries, i.e., Lao PDR, Vietnam, Cambodia, Thailand, the Philippines, Taiwan, China, and Korea. This helminth group causes serious economic damage in the industry of fish aquaculture [1-4]. FZH infections in humans are mainly localized in riverside areas, in which riparian residents are vulnerable to be infected by habitual consumption of raw and/or fermented fish containing infective larvae. Especially, the riverside areas in Mekong river basin in Vietnam, Lao PDR, Cambodia, and Thailand are known to be highly

- Received 20 September 2020, revised 27 September 2020, accepted 3 October 2020. *Corresponding author (wmsohn@gnu.ac.kr)

(c) 2020, Korean Society for Parasitology and Tropical Medicine

This is an Open Access article distributed under the terms of the Creative Commons Attribution Non-Commercial License (https://creativecommons.org/licenses/by-nc/4.0) which permits unrestricted non-commercial use, distribution, and reproduction in any

medium, provided the original work is properly cited. endemic with FZH infections [5-9].

Epidemiological studies on helminthic infections have not been actively performed in the Republic of the Union of Myanmar (Myanmar). Most studies if any were surveys on soil-transmitted helminthiases [10-14]. However, Aung et al. [15] and Sohn et al. [16] reported the endemic status of opisthorchiasis in Myanmar. Won et al. [17] molecularly diagnosed 2 cases of Taenia saginata infection in Yangon, Myanmar. Chai et al. [18] surveyed the infection status of zoonotic trematode metacercariae (ZTM) in fish from a local market in Yangon, and they described the morphological characteristics of adult flukes recovered from experimental animals. On the other hand, surveys on larval gnathostome infections in fish hosts were performed 3 times in Myanmar [19-21]. Chai et al. [19] examined 10 freshwater fish in 3 species, i.e., 6 catfish (Parasilurus sp.), 3 freshwater breams (Tilapia sp.), and 1 snakehead (Channa sp.), from Yangon, Myanmar. Jung et al. [20] exam- 
ined total 15 snakeheads (Channa striata) from a suburban area of Naypyidaw (the capital of Myanmar). Chai et al. [21] surveyed larval gnathostome infections in 37 Asian swamp eels (Monopterus albus) purchased from a local market in Yangon. These studies were performed with limited numbers of fish in limited fish species, and/or probable fish hosts of Gnathostoma spp. Therefore, in the present study, we examined total 486 fish in 13 species to reveal the infection status of zoonotic helminth larvae (ZHL), including larval gnathostomes and ZTM, in Yangon, Myanmar.

We purchased a total of 486 fish of 13 species in a local market in North Dagon District [14], Yangon City, Myanmar, 8 times (December 2015, August and November 2016, November 2017, June and December 2018, 2019). All collected fish were transported with ice to the laboratory of Department of Parasitology and Tropical Medicine, Gyeongsang National University College of Medicine, Jinju, Korea. The length and weight of fish were individually measured and identified the fish species with the aid of the FishBase website (http://www. fishbase.org/search.php) (Table 1) [22]. Individual fish was finely ground with a mortar and pestle, the ground fish meat was mixed with artificial gastric juice and the mixture was incubated at $36^{\circ} \mathrm{C}$ for about $2 \mathrm{hr}$. The digested material was filtered through a $5 \times 5 \mathrm{~mm}^{2}$ mesh, and washed with $0.85 \%$ saline until the supernatant became clear. The sediment was carefully examined under a stereomicroscope. Larval gnathostomes and ZTM were separately collected viewing from the general feature, and were counted to get hold of the prevalence (\%) and intensity of infection (no. of larvae per fish infected) by fish species $[18,21]$.

Larval gnathostomes were detected from 58 (16.0\%) out of 362 fish of 6 species (46.2\%), i.e., Channa lucius, Anabas testudineus, Chelon macrolepis, Channa striata, Heteropneustes kemratensis, and Channa sp., and their mean intensity was 2.8 per fish infected. The infection status of larval gnathostomes by fish species is presented in Table 2. The advanced third-stage larvae $\left(\mathrm{AdL}_{3}\right)$ of gnathostomes detected $(\mathrm{n}=17)$ from forest snakeheads, C. lucius, and climbing perch, A. testudineus were

Table 1. Fish purchased in a local fish market in North Dagon District, Yangon City, Myanmar

\begin{tabular}{|c|c|c|c|c|c|}
\hline \multirow{2}{*}{ Fish species } & \multirow{2}{*}{$\begin{array}{l}\text { No. of fish } \\
\text { collected }^{a}\end{array}$} & \multicolumn{2}{|c|}{ Length (cm) } & \multicolumn{2}{|c|}{ Weight (g) } \\
\hline & & Range & Average & Range & Average \\
\hline Channa lucius & 105 & $9.9-19.4$ & 13.5 & $15.7-152.3$ & 46.9 \\
\hline Anabas testudineus & 100 & 7.3-14.7 & 11.4 & $12.7-115.0$ & 52.5 \\
\hline Thynnichthys thynnoides & 79 & $7.3-16.0$ & 9.1 & 6.8-87.5 & 17.9 \\
\hline Chelon macrolepis & 78 & $6.2-18.0$ & 12.4 & $3.1-97.9$ & 38.9 \\
\hline Puntius aurotaeniatus & 15 & 4.6-9.2 & 5.2 & 2.3-8.2 & 3.4 \\
\hline Heteropneustes kemratensis & 14 & $13.2-18.7$ & 16.7 & $26.0-83.5$ & 55.8 \\
\hline Cirrhinus cirrhosis & 10 & $13.8-26.0$ & 17.2 & 39.3-293.2 & 99.2 \\
\hline Puntioplites sp. & 10 & 7.4-13.8 & 10.0 & 8.8-58.4 & 24.4 \\
\hline Channa sp. & 10 & $13.5-18.6$ & 16.2 & 39.3-92.6 & 70.8 \\
\hline Hypsibarbus lagleri & 7 & $9.7-14.4$ & 12.3 & $22.2-76.3$ & 50.4 \\
\hline Esomus altus & 1 & - & 9.5 & - & 8.0 \\
\hline
\end{tabular}

${ }^{a} A$ total of 486 fish in 13 species.

Table 2. Infection status of Gnathostoma sp. larvae by species of fish from Yangon City, Myanmar

\begin{tabular}{|c|c|c|c|c|}
\hline \multirow{2}{*}{ Fish species } & \multirow{2}{*}{ No. of fish examined } & \multirow{2}{*}{ No. of fish infected (\%) } & \multicolumn{2}{|c|}{ No. of larvae detected } \\
\hline & & & Range & Average \\
\hline Channa lucius & 105 & $24(22.9)$ & $1-18$ & 4.5 \\
\hline Anabas testudineus & 100 & $18(18.0)$ & $1-2$ & 1.2 \\
\hline Chelon macrolepis & 78 & $2(2.6)$ & - & 1.0 \\
\hline Channa striata & 55 & $11(20.0)$ & $1-11$ & 2.9 \\
\hline Channa sp. & 10 & $2(20.0)$ & - & 1.0 \\
\hline Total & 362 & $58(16.0)$ & $1-18$ & 2.8 \\
\hline
\end{tabular}


2.05-3.90 (av. 2.911) mm long and 0.20-0.36 (av. 0.311) mm wide. They had a characteristic head bulb (av. $0.077 \times 0.187$ $\mathrm{mm}$ ) with 4 rows of hooklets, a muscular long esophagus (av. $0.955 \mathrm{~mm}$ long), 2 pairs of cervical sac (av. $0.580 \mathrm{~mm}$ long), and a short tail (av. $0.059 \mathrm{~mm}$ long). The mean number of hooklets was 40, 43, 46, and 48 on the 1st, 2nd, 3rd, and 4th row, respectively. They were more or less smaller than those (from swamp eels and Chinese edible frogs) of previous studies in Myanmar [21,23].

More than 8 species, i.e., Opisthorchis viverrini, Haplorchis taichui, H. pumilio, H. yokogawai, Centrocestus spp., Stellantchasmus falcatus, Pygidiopsis cambodiensis, and Procerovum sp., of ZTM were detected. The metacercariae of $O$. viverrini were found in $10(2.9 \%)$ out of 349 fish in 5 species (38.5\%), i.e., C. lucius, A. testudineus, Thynnichthys thynnoides, C. striata, and Puntioplites sp. and their mean intensity was 16.9 per fish infected (Table 3). The metacercariae of $H$. taichui were detected from 45 (16.8\%) out of 268 fish in 7 species (53.9\%), and their mean intensity was 63.3 per fish infected (Table 4 ). The metacercariae of $H$. pumilio were found in 102 (26.0\%) out of 393 fish in 10 species (76.9\%), and their mean intensity was 26.8 per fish infected (Table 5). H. yokogawai metacercariae were detected in $13(12.5 \%)$ out of 104 fish in 3 species (23.1\%), and their mean intensity was 86.2 per fish infected. Centrocestus spp.

Table 3. Infection status of Opisthorchis viverrini metacercariae by species of fish from Yangon City, Myanmar

\begin{tabular}{lccrc}
\hline \multirow{2}{*}{ Fish species } & No. of fish examined & No. of fish infected (\%) & \multicolumn{2}{c}{ No. of metacercariae detected } \\
\cline { 4 - 5 } & & & Range & Average \\
\hline Channa lucius & 105 & $6(5.7)$ & $1-50$ & 21.2 \\
Anabas testudineus & 100 & $1(1.0)$ & - & 1.0 \\
Thynnichthys thynnoides & 79 & $1(1.3)$ & - & 2.0 \\
Channa striata & 55 & $1(1.8)$ & - & 38.0 \\
Puntioplites sp. & 10 & $1(10.0)$ & $1-50$ & 1.0 \\
Total & 349 & $10(2.9)$ & 16.9 \\
\hline
\end{tabular}

Table 4. Infection status of Haplorchis taichui metacercariae by species of fish from Yangon City, Myanmar

\begin{tabular}{lrcrc}
\hline \multirow{2}{*}{ Fish species } & No. of fish examined & No. of fish infected (\%) & \multicolumn{2}{c}{ No. of metacercariae detected } \\
\cline { 3 - 4 } & & & Range & Average \\
\hline Channa lucius & 105 & $3(1.3)$ & $2-6$ & 4.3 \\
Thynnichthys thynnoides & 79 & $17(21.5)$ & $1-61$ & 7.9 \\
Channa striata & 55 & $3(5.5)$ & $2-36$ & 17.0 \\
Puntioplites sp. & 10 & $8(80.0)$ & $1-728$ & 163.5 \\
Hypsibarbus lagleri & 7 & $2(28.6)$ & $1-3$ & 2.0 \\
Ctenopharyngodon idella & 2 & $2(100)$ & $6-10$ & 8.0 \\
Total & 268 & $45(16.8)$ & $1-728$ & 63.3 \\
\hline
\end{tabular}

Table 5. Infection status of Haplorchis pumilio metacercariae by species of fish from Yangon City, Myanmar

\begin{tabular}{|c|c|c|c|c|}
\hline \multirow{2}{*}{ Fish species } & \multirow{2}{*}{ No. of fish examined } & \multirow{2}{*}{ No. of fish infected (\%) } & \multicolumn{2}{|c|}{ No. of metacercariae detected } \\
\hline & & & Range & Average \\
\hline Channa lucius & 105 & $23(21.9)$ & $1-890$ & 94.9 \\
\hline Anabas testudineus & 100 & $18(18.0)$ & $1-17$ & 6.2 \\
\hline Thynnichthys thynnoides & 79 & $30(38.0)$ & $1-12$ & 2.5 \\
\hline Channa striata & 55 & $9(16.4)$ & $1-20$ & 6.6 \\
\hline Channa sp. & 10 & $2(20.0)$ & $1-92$ & 46.5 \\
\hline Puntioplites sp. & 10 & $8(80.0)$ & $1-728$ & 3.1 \\
\hline Cirrhinus cirrhosis & 10 & $4(40.0)$ & & 4.0 \\
\hline Hypsibarbus lagleri & 7 & $6(85.7)$ & $1-3$ & 27.0 \\
\hline Ctenopharyngodon idella & 2 & $1(50.0)$ & - & 1.0 \\
\hline Total & 393 & $102(26.0)$ & $1-890$ & 26.8 \\
\hline
\end{tabular}


metacercariae were found in $54(15.0 \%)$ out of 359 fish in 6 species (46.2\%), and their mean intensity was 8.7 per fish infected. The infection status of $H$. yokogawai and Centrocestus spp. metacercariae by fish species are presented in detail in Tables 6 and 7. The metacercariae of S. falcatus and P. cambodiensis were detected in $8(10.3 \%)$ and $11(14.1 \%)$ out of 78 mullet, C. macrolepis, examined, and their mean intensities were 9.9 per fish infected each. Procerovum sp. metacercariae were found in 4 (7.3\%) striped snakehead, C. striata, and 1 (1.0\%) climbing perch, A. testudineus, and their mean intensities were 44.0 and 21.0 per fish infected.

In the present study, more than 9 species, i.e., Gnathostoma sp., O. viverrini, H. taichui, H. pumilio, H. yokogawai, S. falcatus, P. cambodiensis, Procerovum sp., and Centrocestus spp., including C. formosanus, of ZHL were detected in fish from a local market of North Dagon District in Yangon City, Myanmar. The presence of these ZHL in fish hosts were already reported in Myanmar [18-21]. However, large-scale surveys with lots of fish samples had not been performed in Myanmar. Therefore, by the present study, it has been reconfirmed that more than 9 etiologic agents of fishborne zoonotic helminthiases are distributed in Yangon, Myanmar. Their infection status, i.e., prevalence and intensity of infection, was clarified in the aspect of host-parasite relationship.

Gnathostomiasis caused by larval Gnathostoma species is clinically characterized by creeping eruption in subcutaneous and intermuscular tissues due to migrating larvae. The larval gnathostomes also occasionally invade the visceral organs, including livers and lungs, eyes, and even the central nerve system including brain [4]. Human cases of gnathostomiasis have occurred sporadically in Myanmar. More than 42 cutaneous cases and over 10 ocular cases have been reported since the first case in 1960 [24-28]. The infection status with larval gnathostomes were investigated in fish and frog hosts 4 times in Myanmar [19-21,23]. Chai et al. [19] found $2 \mathrm{AdL}_{3}$ of $\mathrm{G}$. spinigerum from 2 catfish in the examination of 10 freshwater fish in 3 species, i.e., Parasilurus sp., Tilapia sp., and Channa sp., from Yangon. Jung et al. [20] also detected $2 \mathrm{AdL}_{3}$ of G. spinigerum in 2 snakeheads, C. striata, from a suburban area of Naypyidaw. Chai et al. [21] detected a total of 401 G. spinigerum $\mathrm{AdL}_{3}$ in 33 (89.2\%) out of 37 Asian swamp eels purchased in a local market of Yangon. Recently, Chai et al. [23] also detected 158 larval gnathostomes in $15(75.0 \%)$ out of 20 Chinese edible frogs, Hoplobatrachus rugulosus, from a local market of Yangon. In this study, larval gnathostomes were found in $58(16.0 \%)$ out of 362 fish in 6 species, i.e., C. lucius, C. striata, A. testudineus, C. macrolepis, H. kemratensis, and unidentified snakehead, and the forest snakehead, C. lucius, was the most prevalent fish host. Thus, 8 fish species, including catfish and swamp eel, already reported, and Chinese edible frogs are suggested to be the potential risk of human gnathostomiasis in Myanmar.

The endemicity of $O$. viverrini metacercariae (prevalence below $3.0 \%$; intensity of infection about 17 per fish infected)

Table 6. Infection status of Haplorchis yokogawai metacercariae by species of fish from Yangon City, Myanmar

\begin{tabular}{lccrc}
\hline \multirow{2}{*}{ Fish species } & No. of fish examined & No. of fish infected (\%) & \multicolumn{2}{c}{ No. of metacercariae detected } \\
\cline { 4 - 5 } & & $2(2.5)$ & Range & Average \\
\hline Thynnichthys thynnoides & 79 & $3(20.0)$ & $1-385$ & 153.0 \\
Puntius aurotaeniatus & 15 & $8(80.0)$ & $5-218$ & 129.3 \\
Puntioplites sp. & 10 & $13(12.5)$ & $1-385$ & 53.3 \\
Total & 104 & & 86.2 \\
\hline
\end{tabular}

Table 7. Infection status of Centrocestus spp. metacercariae by species of fish from Yangon City, Myanmar

\begin{tabular}{lcccr}
\hline \multirow{2}{*}{ Fish species } & No. of fish examined & No. of fish infected (\%) & \multicolumn{2}{c}{ No. of metacercariae detected } \\
\cline { 4 - 5 } Channa lucius & 105 & $14(13.3)$ & $1-31$ & 6.4 \\
Anabas testudineus & 100 & $14(14.0)$ & $2-58$ & 19.7 \\
Thynnichthys thynnoides & 79 & $16(20.3)$ & $1-5$ & 2.1 \\
Channa striata & 55 & $4(7.3)$ & $2-41$ & 12.5 \\
Channa sp. & 10 & $2(20.0)$ & $1-11$ & 6.0 \\
Puntioplites sp. & 10 & $4(40.0)$ & $1-3$ & 2.0 \\
Total & 359 & $54(15.0)$ & $1-58$ & 8.7 \\
\hline
\end{tabular}


was very low like in Sohn et al. [16]. Among 5 positive fish species, 4, i.e., C. lucius, C. striata, A. testudineus, and unspecified Puntioplites sp., were previously reported [16], and only 1 species, T. thynnoides, is newly added to the second intermediate hosts of O. viverrini in Myanmar. The low-grade endemicity for opisthorchiasis in Myanmar was also confirmed by fecal examinations of people [15,16]. Aung et al. [15] found small trematode eggs in $34(9.3 \%)$ out of 364 fecal samples of residents, and molecularly confirmed 18 cases to be opisthorchiasis infections. Sohn et al. [16] also detected small trematode eggs from $14(0.7 \%)$ out of 2,057 fecal samples in 3 regions in Yangon. Accordingly, it is suggested that opisthorchiasis is maintained in low grade in the second intermediate fish host as well as in the definitive human host in Myanmar.

In the present study, $H$. taichui metacercariae were detected from 45 (16.8\%) out of 268 fish in 7 (53.8\%) species, i.e., C. lucius, C. striata, T. thynnoides, C. cirrhosis, H. lagleri, C. idella, and unspecified Puntioplites sp., and their mean intensity was 63.3 per fish infected. The prevalence was lower than that $(42.3 \%)$ of Chai et al. [18], but the intensity of infection was more or less higher than that (42.9) of a previous study performed in Yangon, Myanmar [18]. Especially, the prevalences and intensities were relatively high in 2 fish species, C. cirrhosis, and Puntioplites sp. By this study and Chai et al. [18], a total of 11 fish species, i.e., C. lucius, C. striata, T. thynnoides, C. cirrhosis, H. lagleri, C. idella, Puntius aurotaeniatus, Esomus altus, Puntioplites sp., Mystacoleucus sp., and Labeo sp., are recorded as the second intermediate hosts of $H$. taichui in Myanmar.

The metacercariae of $H$. pumilio were detected from 102 (26.0\%) out of 393 fish in 10 (76.9\%) species, i.e., C. lucius, C. striata, A. testudineus, T. thynnoides, C. cirrhosis, H. lagleri, C. idella, P. aurotaeniatus, Puntioplites sp., and Channa sp., and their mean intensity was 26.8 per fish infected. The prevalence and intensity of infection were relatively low like in a previous study [18]. Based on the findings of present and previous studies, total 15 fish species, i.e., C. lucius, C. striata, A. testudineus, T. thynnoides, C. cirrhosis, H. lagleri, C. idella, P. aurotaeniatus, Trichogaster pectoralis, E. altus, Puntioplites sp., Channa sp., Rhynogobius sp., Mystacoleucus sp., and Labeo sp., are the second intermediate hosts of $H$. pumilio in Myanmar. In Chai et al. [18], H. yokogawai metacercariae were found in 5 fish species, i.e., $P$. aurotaeniatus, E. altus, T. pectoralis, Mystacoleucus sp., and Labeo sp., from Yangon, Myanmar, and they were heavily infected in 2 fish species, $P$. aurotaeniatus and Mystacoleucus sp. However, $H$. yokogawai metacercariae were detected in 3 fish species, Puntio- plites sp., P. aurotaeniatus, and T. thynnoides, in this study. Therefore, total 7 fish species, i.e., P. aurotaeniatus, E. altus, T. pectoralis, T. thynnoides, Puntioplites sp., Mystacoleucus sp., and Labeo sp., have been found to be the second intermediate hosts of $H$. yokogawai in Myanmar.

Centrocestus spp. metacercariae, including C. formosanus, were found in 6 (46.2\%) fish species, i.e., C. lucius, C. striata, A. testudineus, T. thynnoides, Puntioplites sp., and Channa sp., and their mean intensity was 8.7 per fish infected. The prevalence $(15.0 \%)$ and intensity of infection were lower than those (50.8\% and 25.8) of Chai et al. [18]. By the present study, 3 fish species, i.e., C. lucius, Puntioplites sp., and Channa sp., are newly added in the second intermediate hosts of Centrocestus spp. in Myanmar. As the second intermediate hosts of Centrocestus spp., a total of 11 fish species, i.e., C. lucius, T. thynnoides, P. aurotaeniatus, E. altus, C. striata, A. testudineus, T. pectoralis, Puntioplites sp., Channa sp., Mystacoleucus sp., and Labeo sp., have been listed in Myanmar.

In the present study, Procerovum sp. metacercariae were detected from 2 fish species, C. striata and A. testudineus, examined in August 2016. The climbing perch, A. testudineus, was previously reported as the second intermediate host of Procerovum spp., including P. varium in Vietnam, Lao PDR, and Myanmar $[9,18,29,30]$. The metacercariae of $S$. falcatus and P. cambodiensis were detected only in mullets, Chelon macrolepis, like in previous studies, including Chai et al. [18,31,32]. Chai et al. [18] detected a total of 36 S. falcatus metacercariae in 15 (34.1\%) out of 44 mullets examined and they also found 38 metacercariae of P. cambodiensis in only 1 (2.2\%) mullet from Yangon, Myanmar. In the present study, the prevalences were 10.3\% and $14.1 \%$ and intensities of infection of 2 heterophyid flukes were commonly 9.9 per fish infected.

Conclusively, it has been confirmed that larval gnathostomes and more than 8 species of ZTM, i.e., O. viverrini, H. taichui, H. pumilio, H. yokogawai, S. falcatus, P. cambodiensis, Procerovum sp., and Centrocestus spp., including $C$. formosanus, were infected in fish from Yangon, Myanmar, and they can act as the etiologic agents of fishborne zoonotic helminthiases although their endemicities were not so high. To reveal the detailed epidemiological situation of FZH infections in Myanmar, further studies on the intermediate and definitive hosts (humans and reservoir host animals) of FZH should be performed in the near future. 


\section{ACKNOWLEDGMENTS}

We thank Jung-A Kim and Hee-Ju Kim, Department of Parasitology and Tropical Medicine, Gyeongsang National University College of Medicine, Jinju, Korea, for their help in fish examinations. We also thank the members of Korea Association of Health Promotion, who participated in the KOICA-KAHP (Korea International Cooperation Agency and Korea Association of Health Promotion) Joint Project in Myanmar (20152019).

\section{CONFLICT OF INTEREST}

The authors don't have any conflicts of interest to declare.

\section{REFERENCES}

1. Chai JY, Murrell KD, Lymbery AJ. Fish-borne parasitic zoonoses: status and issues. Int J Parasitol 2005; 35: 1233-1254. https:// doi.org/10.1016/j.ijpara.2005.07.013

2. Chai JY. Intestinal flukes. In Murrell $\mathrm{KD}$, Fried B eds, Food-borne parasitic zoonoses. New York, USA. Springer. 2007, pp 53-115.

3. Hung NM, Madsen H, Fried B. Global status of fish-borne zoonotic trematodiasis in humans. Acta Parasitol 2013; 58: 231-258. https://doi.org/10.2478/s11686-013-0155-5

4. Herman JS, Chiodini PL. Gnathostomiasis, another emerging imported disease. Clin Microbiol Rev 2009; 22: 484-492. https:// doi.org/10.1128/CMR.00003-09

5. Radomyos B, Wongsaroy T, Wilairatana P, Radomyos P, Praevanich $\mathrm{R}$, Meesomboon $\mathrm{V}$, Jongsuksuntikul P. Opisthorchiasis and intestinal fluke infections in northern Thailand. Southeast Asian J Trop Med Public Health 1998; 29: 123-127.

6. Chai JY, Park JH, Han ET, Guk SM, Shin EH, Lin A, Kim JL, Sohn WM, Yong TS, Eom KS, Min DY, Hoang EH, Phommasack B, Insisienmay B, Rim HJ. Mixed infections with Opisthorchis viverrini and intestinal flukes in residents of Vientiane Municipality and Saravane Province in Laos. J Helminthol 2005; 79: 283-289. https://doi.org/10.1079/joh2005302

7. Chai JY, Han ET, Shin EH, Sohn WM, Yong TS, Eom KS, Min DY, Um JY, Park MS, Hoang EH, Phommasack B, Insisienmay B, Lee $\mathrm{SH}$, Rim HJ. High prevalence of Haplorchis taichui, Prosthodendrium molenkampi, and other helminth infections among people in Khammouane Province, Lao PDR. Korean J Parasitol 2009; 47: 243-247. https://doi.org/10.3347/kjp.2009.47.3.243

8. Dung DT, De NV, Waikagul J, Dalsgaard A, Chai JY, Sohn WM, Murrell KD. Fishborne intestinal zoonotic trematodiasis, Vietnam. Emerg Infect Dis 2007; 13: 1828-1833. https://doi.org/10.3201/ eid1312.070554

9. Phan VT, Ersbøll AK, Nguyen KV, Madsen H, Dalsgaard A. Farmlevel risk factors for fishborne zoonotic trematode infection in integrated small-scale fish farms in northern Vietnam. PLoS Negl Trop Dis 2010; 4: 742-750. https://doi.org/10.1371/journal. pntd.0000742

10. Nuchprayoon S, Sanprasert V, Kaewzaithim S, Saksirisampant W. Screening for intestinal parasitic infections among Myanmar migrant workers in Thai food industry: a high-risk transmission. J Immigrant Minority Health 2009; 11: 115-121. https://doi.org/10. 1007/s10903-008-9169-8

11. Htwe KT, Min TT, Mar TT, Lwin MM, Maw WW, Win MM. Detection of intestinal parasitic infestation among primary school children, Magway. Myanmar Health Sci Res J 2010; 22: 89-94.

12. Aung T, Myat SM, Gabrielli AF, Montresor A. Control of soiltransmitted helminthiasis in Myanmar: Result of 7 years of deworming. Trop Med Int Health 2013; 18: 1017-1020. https://doi. org/10.1111/tmi.12130

13. Htoon TT, Tun T, Oo KY, Thein W, Tin HH, Chai JY, Yong TS, Sohn WM. Status of infection with soil-transmitted helminths among primary school children in three selected townships of Yangon region. Myanmar Health Sci Res J 2015; 27: 221-226.

14. Chai JY, Sohn WM, Hong SJ, Jung BK, Hong S, Cho S, Park JB, Kim IS, Kim S, Lee KH, Jeoung HG, Htoon TT, Tin HH. Effect of mass drug administration with a single dose of albendazole on Ascaris lumbricoides and Trichuris trichiura infection among schoolchildren in Yangon region, Myanmar. Korean J Parasitol 2020; 58: 195-200. https://doi.org/10.3347/kjp.2020.58.2.195

15. Aung WPP, Htoon TT, Tin HH, Thinn KK, Sanpool O, Jongthawin J, Sadaow L, Phosuk I, Rodpai R, Intapan PM, Maleewong W. First report and molecular identification of Opisthorchis viverrini infection in human communities from lower Myanmar. PLoS One, 2017; 12: e0177130. https://doi.org/10.1371/journal. pone. 0177130

16. Sohn WM, Jung BK, Hong SJ, Lee KH, Park JB, Kim HS, Cho S, Htoon TT, Tin HH, Chai JY. Low-grade endemicity of opisthorchiasis, Yangon, Myanmar. Emerg Infect Dis 2019; 25: 1435-1437. https://doi.org/10.3201/eid2507.190495

17. Won EJ, Jung BK, Song HM, Kim MS, Kim HS, Lee KH, Kim MJ, Shin MG, Shin JH, Suh SP, Hong SJ, Sohn WM, Htoon TT, Tin HH, Chai JY. Molecular diagnosis of Taenia saginata tapeworm infection in 2 schoolchildren, Myanmar. Emerg Infect Dis 2018; 24: 1156-1158. https://doi.org/10.3201/eid2406.180217

18. Chai JY, Sohn WM, Na BK, Park JB, Jeoung HG, Hoang EH, Htoon TT, Tin HH. Zoonotic trematode metacercariae in fish from Yangon, Myanmar and their adults recovered from experimental animals. Korean J Parasitol 2017; 55: 631-641. https:// doi.org/10.3347/kjp.2017.55.6.631

19. Chai JY, Han ET, Shin EH, Park JH, Chu JP, Hirota M, Nakamura F, Nawa Y. An outbreak of gnathostomiasis among Korean emigrants in Myanmar. Am J Trop Med Hyg 2003; 69: 67-73.

20. Jung BK, Lee JJ, Pyo KH, Kim HJ, Jeong HG, Yoon CH, Lee SH, Shin EH, Chai JY. Detection of Gnathostoma spinigerum thirdstage larvae in snakeheads purchased from a central part of Myanmar. Korean J Parasitol 2008; 46: 285-288. https://doi.org/10.3347/ kjp.2008.46.4.285 
21. Chai JY, Sohn WM, Na BK, Park JB, Jeoung HG, Hoang EH, Htoon TT, Tin HH. Larval Gnathostoma spinigerum detected in Asian swamp eels, Monopterus albus, purchased from a local market in Yangon, Myanmar. Korean J Parasitol 2015; 53: 619-625. https://doi.org/10.3347/kjp.2015.53.5.619

22. Search FishBase [Internet]; Available from: http://www.fishbase. org/search.php

23. Chai JY, Jung BK, Lee KH, Ryu JY, Kim HS, Hong SJ, Htoon TT, Tin HH, Na BK, Sohn WM. Larval gnathostomes and spargana in Chinese edible frogs, Hoplobatrachus rugulosus, from Myanmar: potential risk of human infection. Korean J Parasitol 2020; 58: 467-473. https://doi.org/10.3347/kjp.2020.58.4.467

24. Gyi K. Intra-ocular gnathostomiasis. Br J Ophthalmol 1960; 44: 42-45. https://doi.org/10.1136/bjo.44.1.42

25. Khin T. Intra-ocular gnathostomiasis. Br J Ophthalmol 1968; 52 : 57-60. https://doi.org/10.1136/bjo.52.1.57

26. Nomura Y, Nagakura K, Kagei N, Tsutsumi Y, Araki K, Sugawara. M. Gnathostomiasis possibly caused by Gnathostoma malaysiae. Tokai J Exp Clin Med 2000; 25: 1-6.

27. Develoux M, Dekumyoy P, Baygon E, Aractingi S. Imported gnathostomiasis acquired in Myanmar. Med Mal Infect 2006; 36: 340342 (in French). https://doi.org/10.1016/j.medmal.2006.01.011
28. Wai AP, Maw WW, Moe AC, Boonmars T, Nawa Y. Human gnathostomiasis in Myanmar: a review of local literature. Southeast Asian J Trop Med Public Health 2018; 49: 543-548.

29. Chai JY, De NV, Sohn WM. Foodborne trematode metacercariae in fish from northern Vietnam and their adults recovered from experimental hamsters. Korean J Parasitol 2012; 50: 317-325. https://doi.org/10.3347/kjp.2012.50.4.317

30. Eom KS, Park HS, Lee D, Sohn WM, Yong TS, Chai JY, Min DY, Rim HJ, Insisiengmay B, Phommasack B. Infection status of zoonotic trematode metacercariae in fishes from Vientiane Municipality and Champasak Province in Lao PDR. Korean J Parasitol 2015; 53: 447-453. https://doi.org/10.3347/kjp.2015.53.4.447

31. Chai JY, Sohn WM, Na BK, Jeoung HG, Sinuon M, Socheat D. Stellantchasmus falcatus (Digenea: Heterophyidae) in Cambodia: discovery of metacercariae in mullets and recovery of adult flukes in an experimental hamster. Korean J Parasitol 2016; 54: 537-541. https://doi.org/10.3347/kjp.2016.54.4.537

32. Sohn WM, Kim DG, Jung BK, Cho J, Chai JY. Pygidiopsis cambodiensis n. sp. (Digenea: Heterophyidae) from experimental hamsters infected with metacercariae in mullets from Cambodia. Parasitol Res 2016; 115: 123-130. https://doi.org/10.1007/s00436-015$4727-1$ 
